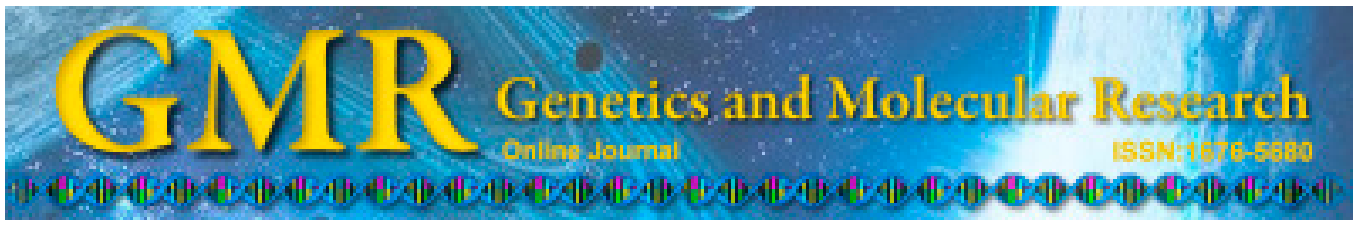

\title{
Expression of hypoxia-inducible factor-1 $\alpha$ during ovarian follicular growth and development in Sprague-Dawley rats
}

\author{
Z.H. Zhang ${ }^{1,2}$, L.Y. Chen ${ }^{1}$, F. Wang ${ }^{1}$, Y.Q. Wu ${ }^{1}$, J.Q. Su${ }^{1}$, X.H. Huang ${ }^{1}$, \\ Y. Cheng ${ }^{2}$ and Z.C. Wang ${ }^{1}$
}

${ }^{1}$ Provincial Key Laboratory for Developmental Biology and Neurosciences, College of Life Sciences, Fujian Normal University, Fuzhou, China ${ }^{2}$ Provincial Research Center for Animal Transgenesis and Biopharming, College of Veterinary Medicine, Yangzhou University, Yangzhou, China

Corresponding author: Z.C. Wang

E-mail: zcwang@fjnu.edu.cn

Genet. Mol. Res. 14 (2): 5896-5909 (2015)

Received July 22, 2014

Accepted December 2, 2014

Published June 1, 2015

DOI http://dx.doi.org/10.4238/2015.June.1.7

\begin{abstract}
Hypoxia-inducible factor- $1 \alpha(\mathrm{HIF}-1 \alpha)$ has been identified as a transcription factor that is involved in diverse physiological and pathological processes in the ovary. In this study, we examined whether HIF- $1 \alpha$ is expressed in a cell- and stage-specific manner during follicular growth and development in the mammalian ovaries. Using immunohistochemistry and Western blot analysis, HIF-1 $\alpha$ expression was observed in granulosa cells specifically and was significantly increased during the follicular growth and development of postnatal rats. Furthermore, pregnant mare serum gonadotropin also induced
\end{abstract}


HIF-1 $\alpha$ expression in granulosa cells and ovaries during the follicular development of immature rats primed with gonadotropin. Moreover, we also examined proliferation cell nuclear antigen, a cell proliferation marker, during follicular growth and development and found that its expression pattern was similar to that of HIF-1 $\alpha$ protein. Granulosa cell culture experiments revealed that proliferation cell nuclear antigen expression may be regulated by HIF-1 $\alpha$. These results indicated that HIF-1 $\alpha$ plays an important role in the follicular growth and development of these 2 rat models. The HIF- $1 \alpha$-mediated signaling pathway may be an important mechanism regulating follicular growth and development in mammalian ovaries in vivo.

Key words: Follicular development; Granulosa cell; Sprague-Dawley rat; Hypoxia-inducible factor- $1 \alpha$; Proliferation cell nuclear antigen;

\section{INTRODUCTION}

In female rats, 2 pituitary gonadotropin hormones, follicle-stimulating hormone (FSH) and luteinizing hormone, control reproductive cyclical events through different signaling pathways, including follicular development, maturation, rupture, and release of fertilizable oocytes (Richards et al., 1995; Luo et al., 2011; Zhang et al., 2011a,b, 2012a,b; Meidan et al., 2013; Wang et al., 2012, 2013; Wu et al., 2012, 2013). The understanding of the regulatory mechanisms controlling the growth and final differentiation of a mammalian follicle has advanced exponentially, but our understanding of fundamental pathways remains incomplete during these dynamic processes. Until recently, hypoxia-inducible factor-1 $\alpha$ (HIF- $1 \alpha$ ) was suggested to be a granulosa cell-derived contractile signal that facilitates the regulation of ovarian functions (Luo et al., 2011; Zhang et al., 2011a,b,c; Wang et al., 2012; Wu et al., 2012).

HIF-1 is a heterodimer protein complex consisting of an alpha subunit of $120 \mathrm{kDa}$ and a beta subunit of 91-94 $\mathrm{kDa}$ (Wu et al., 2012). The HIF-1 $\alpha$ subunit is unique to HIF-1 and is regulated by hypoxia signals, which must combine with the HIF-1 $\alpha$ subunit to form HIF-1 and then activate the susceptible gene of hypoxia to lead to adaptive responses involved in hypoxia physiology (Grimshaw, 2007; Gómez-Raposo et al., 2009). During the growth and development of ovarian follicles, the microenvironment in the follicles is considered to be hypoxic, which is the major factor regulating HIF-1 $\alpha$ expression (Zhang et al., 2012b; Wang et al., 2012). Thus, HIF-1 $\alpha$ can regulate the expression of numerous target genes and play a critical role in many important biological effects, including ovarian functions (Richards et al., 1995; Luo et al., 2011; Zhang et al., 2011a,b, 2012a,b; Meidan et al., 2013; Wang et al., 2012, 2013; Wu et al., 2012, 2013). Moreover, recent studies found that HIF-1 $\alpha$ can be regulated by reproductive hormones (Luo et al., 2011; Zhang et al., 2011a,b; 2012a,b; Meidan et al., 2013; Wang et al., 2012, 2013; Wu et al., 2012, 2013). These studies indicate that HIF-1 $\alpha$ is involved in follicular development in the mammalian ovary.

The transcription factor HIF-1 $\alpha$ is thought to be a critical regulatory factor during the development of physiological systems and as a key regulator of body tissue homeostasis involved in regulating cell survival/adaptation, anaerobic metabolism, immune response, cytokine secretion, and angiogenesis (Richards et al., 1995; Grimshaw, 2007; Gómez-Raposo et al., 2009; Luo et al., 2011; Zhang et al., 2011a,b, 2012a,b; Wang et al., 2012, 2013; Wu et al., 2012, 2013; 
Meidan et al., 2013). Given the role of HIF-1 $\alpha$ in ovarian functions, we used follicular development models of postnatal and pregnant mare serum gonadotrophin (PMSG)-induced immature rats to investigate the expression of HIF- $1 \alpha$ in the ovaries. We examined changes in HIF-1 $\alpha$ and proliferating cell nuclear antigen (PCNA) during follicular development based on the follicular development characteristics of these 2 model animals. The goal of this study was to further understand the role of HIF- $1 \alpha$ during follicular development in the mammalian ovary.

\section{MATERIAL AND METHODS}

\section{Animals}

Sprague-Dawley rats were purchased from Wushi Experimental Animal Supply Co., Ltd. (Fuzhou, China). The animals were maintained under a 14-h light/10-h dark schedule with a continuous supply of chow and water. The experimental protocol was in accordance with the Guide for the Care and Use of Laboratory Animals prepared by the Institutional Animal Care and Use Committee and approved by Fujian Normal University.

\section{Experimental design}

Two rat models and granulosa cell culture were used in the current experiment.

1) Postnatal rat model (Wang et al., 2007): neonatal rats were obtained by mating adult Sprague-Dawley males and females. After birth, neonatal rats at 1, 5, 7, 10, and 21 days of age (the day of birth was considered day 1) were sampled under ether anesthesia, and the ovaries were immediately collected.

2) Gonadotropin-primed immature rat model (Wang et al., 2007): follicular development was induced by treatment of immature rats (23-25 days old) with 10 IU PMSG (Sigma, St. Louis, MO, USA). Animals were sampled after $48 \mathrm{~h}$ of PMSG treatment under ether anesthesia, and the ovaries were immediately collected.

3) Granulosa cell culture experiment (Zhang et al., 2012a): granulosa cells were isolated from immature rat ovaries and cultured with HIF- $1 \alpha$ small interfering RNA (siRNA) and scrambled siRNA transfection.

One ovary from each rat was fixed in $4 \%$ paraformaldehyde for immunohistochemistry analysis, while the other ovary was snap-frozen and used for western blot and real-time polymerase chain reaction (PCR) analyses. Treated granulosa cells were directly used for realtime PCR.

\section{Immunohistochemistry of PCNA and HIF-1 $\alpha$}

After fixation, ovaries from neonatal and immature rats were embedded in paraffin, and then 5 - $\mu \mathrm{m}$ sections were cut and mounted on slides. The sections were then processed for immunohistochemical analysis with mouse anti-HIF-1 $\alpha$ antibody (1:500, Abcam, Cambridge, MA, USA) and rabbit anti-PCNA antibody (1:500, Abcam). The sections were incubated at room temperature overnight with primary antibody. The immunoreactivity assay of specific protein was visualized using the Elite ABC kit (BioGenex, San Ramon, CA, USA). The negative control was examined using normal mouse or rabbit serum rather than primary antibody (Boster Biological Technology, Wuhan, China). The sections were then counter-stained with hematoxylin 
and mounted with coverslips for the identification of structures and types of cells in the rat ovary.

\section{RNA extraction and real-time PCR analysis of PCNA mRNA and HIF-1 $\alpha$ mRNA}

Total RNA was extracted from the ovaries or granulosa cells using TRIzol solution (Life Technologies, Carlsbad, CA, USA) and then reverse-transcribed (cDNA Synthesis Kit, Cat. No.: 170-8891; Bio-Rad, Hercules, CA, USA). The conditions used for reverse transcription were $25^{\circ} \mathrm{C}$ for $5 \mathrm{~min}, 42^{\circ} \mathrm{C}$ for $30 \mathrm{~min}, 85^{\circ} \mathrm{C}$ for $5 \mathrm{~min}$, and then hold at $4{ }^{\circ} \mathrm{C}$. The reverse-transcribed products were amplified using a TaqMan Gene Expression Assays kit (Applied Biosystems, Foster City, CA, USA), including TaqMan Universal PCR Master Mix (Ref. No.: 4304437), HIF-1 $\alpha$ primer (Ref. No.: Rn00577560_m1), and PCNA primer (Ref. No.: Rn01514538_g1). A kit to detect the levels of 18S ribosomal RNA (Ref. No.: Hs99999901_s1) was used as an endogenous control. Relative gene expression was calculated using the $\bar{\Delta} \overline{\mathrm{Ct}}$ method. The conditions for quantitative PCR were $50^{\circ} \mathrm{C}$ for $2 \mathrm{~min}, 95^{\circ} \mathrm{C}$ for $10 \mathrm{~min}, 40$ cycles at $95^{\circ} \mathrm{C}$ for $15 \mathrm{~s}$, and $60^{\circ} \mathrm{C}$ for $60 \mathrm{~s}$; the reaction was held at $4^{\circ} \mathrm{C}$. Relative mRNA levels were expressed as $2^{-\Delta \Delta \mathrm{Ct}}$ values.

\section{Western blot analysis of PCNA and HIF-1 $\alpha$ proteins}

Protein samples were obtained using the Nuclear and Cytoplasmic Protein Extraction Kit (Beyotime Institute of Biotechnology, Haimen, China). Protein concentrations were determined using a Bio-Rad assay with bovine serum albumin standards. Next, $20 \mu \mathrm{g}$ protein samples were subjected to $8 \%$ sodium dodecyl sulfate-polyacrylamide gel electrophoresis followed by electrophoretic transfer onto a polyvinylidene fluoride membrane. The membrane was washed and probed with anti-HIF-1 $\alpha$ antibody (1:500, Abcam) overnight at $4^{\circ} \mathrm{C}$. After washing, the membranes were incubated with horseradish peroxidase-labeled goat anti-mouse IgG (1:5000, Novus Biologicals, Littleton, CO, USA) for $60 \mathrm{~min}$ at room temperature, and then the film was developed to visualize the results. After HIF-1 $\alpha$, the membrane was reprobed for PCNA expression using anti-PCNA antibody (1:1000, Abcam). To detect the immunoblotting signal, $2 \mathrm{~mL}$ enhanced chemiluminescence detection solution was added, and the membrane was wrapped and exposed to Kodak OMAT film.

\section{Isolation and culture of granulosa cells}

Ovaries were collected from gonadotropin-primed immature rats and granulosa cells were isolated by follicular puncture. Briefly, granulosa cells were collected in Dulbecco's modified Eagle medium/F-12 culture medium (Gibco, Grand Island, NY, USA) containing 5\% fetal bovine serum and $20 \mu \mathrm{g} / \mathrm{mL}$ gentamicin. Cells were washed 3 times in the culture medium, plated on serum-coated 6-well plates at a density of approximately $1 \times 10^{6}$ cells per well, and cultured in a cell culture incubator with a humidified atmosphere of $5 \% \mathrm{CO}_{2}$ in air at $37.5^{\circ} \mathrm{C}$. To examine the effects of PMSG on PCNA and HIF- $1 \alpha$ expression in vitro, granulosa cells were collected from the ovaries of gonadotropin-primed rats and cultured with/without PMSG for $6 \mathrm{~h}$ after scramble siRNA and HIF- $1 \alpha$ siRNA transfection. All cultures were performed in duplicate and replicated 3 times on different days. All cell samples were examined by real-time PCR. 


\section{Transfection of HIF-1 $\alpha$ siRNA}

When cell fusion was approximately $85 \%$, siRNA transfection was performed using the siLentFect Lipid Reagent (Bio-Rad) according to manufacturer instructions (Zhang et al., 2012a). For a $10-\mathrm{cm}$ dish, 200 pmol siRNA was used. After $5 \mathrm{~h}$ incubation in transfection reagent, the cells were switched to normal medium for an additional $16 \mathrm{~h}$ and were then ready for the experiment. The sequence of HIF-1 $\alpha$ siRNA was: sense, 5'-GGA AAG AGA CUC AUA GAA A-3', antisense, 5'-UUU CUA UGA CUC UCU UUC C-3', (Sigma). A scrambled small RNA (sense, 5'-UUC UCC GAA CGU GUC ACG U-3', antisense, 5'-ACG UGA CAC GUU CGG AGA A-3', Qiagen, Hilden, Germany), which was confirmed to be a non-silencing double-stranded RNA, was used as a control for siRNA experiments.

\section{Statistical analysis}

Data are reported as means $\pm \mathrm{SEM}$. The significance of differences in mean values within and between multiple groups was evaluated using one-way analysis of variance, followed by a Tukey multiple range test. The Student $t$-test was used to evaluate statistical significance of differences between 2 groups. $\mathrm{P}<0.05$ was considered to be statistically significant.

\section{RESULTS}

\section{Follicular development and HIF-1 $\alpha$ immunohistochemistry in the postnatal rats}

Our morphological examination showed that typical histological changes were consistent with those observed in our previous report (Wang et al., 2007). At postnatal day 1 , the ovary contained only primordial follicles with an oocyte partially or completely encapsulated by squamous pre-granulosa cells (Figure 1A), and HIF-1 $\alpha$ immunoreactivities were markedly localized to the oocytes (Figure 1B). At postnatal day 5, the largest follicles contained 3 layers of granulosa cells and began to form a partial layer of the theca interna (Figure 1C), and immunoreactive staining of HIF-1 $\alpha$ was detected in the oocytes and granulosa cells of primary follicles (Figure 1D). At postnatal day 7, the largest follicles showed an antrum and contained 2-3 layers of theca cells (Figure 1E), and HIF-1 $\alpha$ immunoreactivities were mainly localized to the oocytes and granulosa cells of primary and secondary follicles (Figure 1F). At postnatal day 10, the largest follicle contained an antrum and at least 3 layers of theca cells (Figure 1G), while at postnatal day 21, the ovary contained large follicles with a well-developed theca interna of 4 layers of theca cells (Figure 1H). HIF-1 $\alpha$ immunoreactivities were markedly localized to the oocytes, granulosa cells, and theca cells of the secondary and early tertiary follicles at days 10 and 21 (Figure 1I and J). Immuohistochemistry revealed that HIF-1 $\alpha$ exists in the granulosa cells during follicular development with the proliferation of granulosa cells in the postnatal rats (Figure 1), implying that HIF-1 $\alpha$ may be involved in the initiation of follicular growth and following development. 

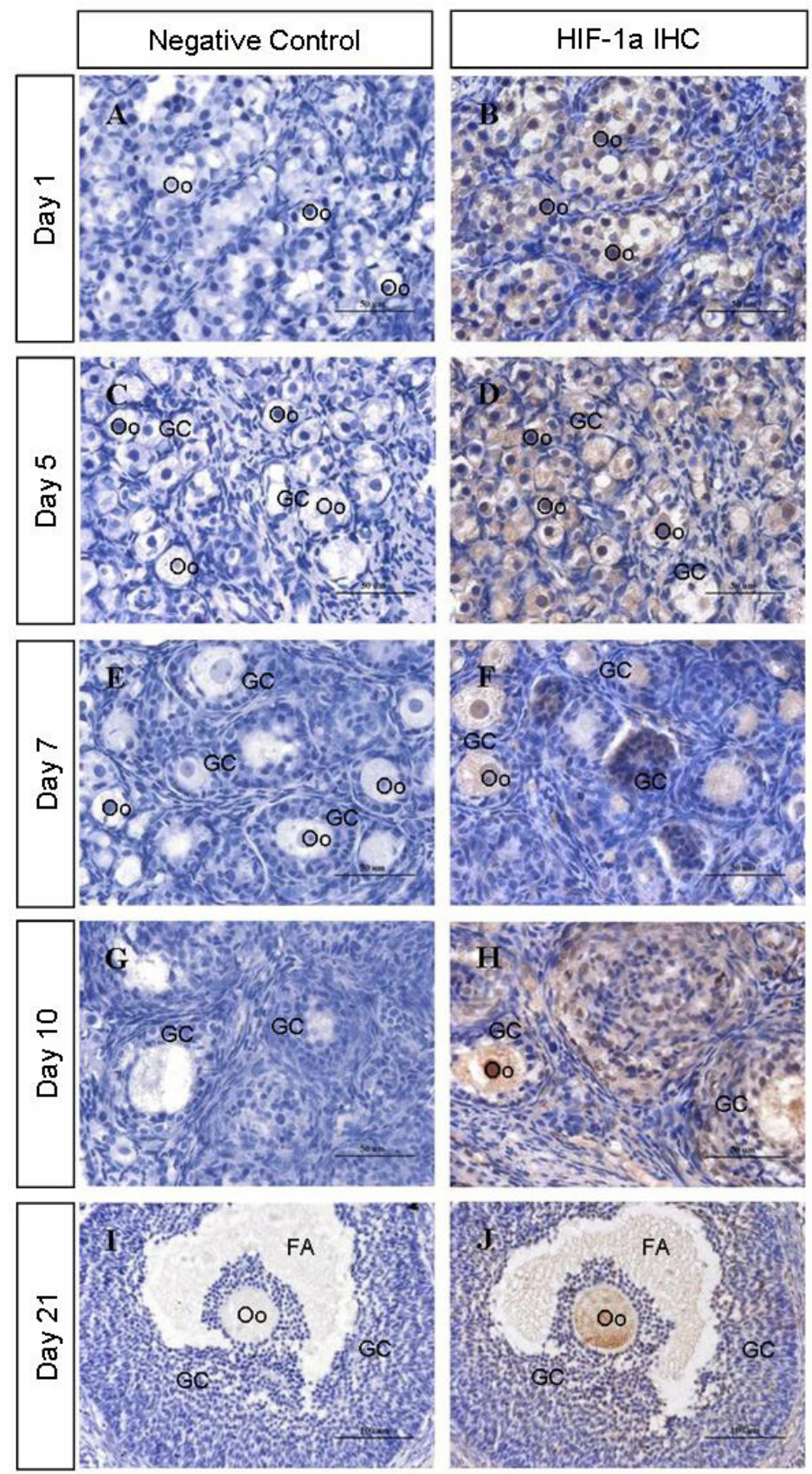

Figure 1. Cellular localization of HIF-1 $\alpha$ protein during follicular growth and development in the ovary on different postnatal days. Ovarian sections were immunostained for HIF-1 $\alpha$ and counterstained with hematoxylin. The HIF$1 \alpha$ immunohistochemical signals were brown and the counterstaining background was blue in color. Negative controls remained unstained in samples lacking primary antibody instead of serum. $\mathrm{N}=6$ animals in each group. GC: granulosa cell, Oo: oocyte, FA: follicle antrum. 


\section{PCNA immunohistochemistry in postnatal rats}

To clarify the role of HIF-1 $\alpha$ in follicular development, we examined expression of the cell proliferation marker PCNA. At postnatal day 1, PCNA immunoreactivities were markedly localized to nearly all cells (Figure 2B). At postnatal day 5, immunoreactive staining of PCNA was detected in the oocytes and granulosa cells of primary follicles (Figure 2C). At postnatal day 7, PCNA immunoreactivities were mainly localized to the oocytes and granulosa cells of primary and secondary follicles (Figure 2D). At postnatal day 10, PCNA immunoreactivities were markedly localized to the oocytes, granulosa cells, and theca cells of secondary follicles (Figure 2E), while at postnatal day 21, PCNA was markedly localized to the oocytes and granulosa cells of secondary and early tertiary follicles (Figure 2F). Immunohistochemistry results for PCNA showed strong staining in proliferating cells (Figure 2), particularly in the granulosa cells, which is consistent with the results for HIF-1 $\alpha$. These results further indicated HIF-1 $\alpha$ may participate in follicular development.

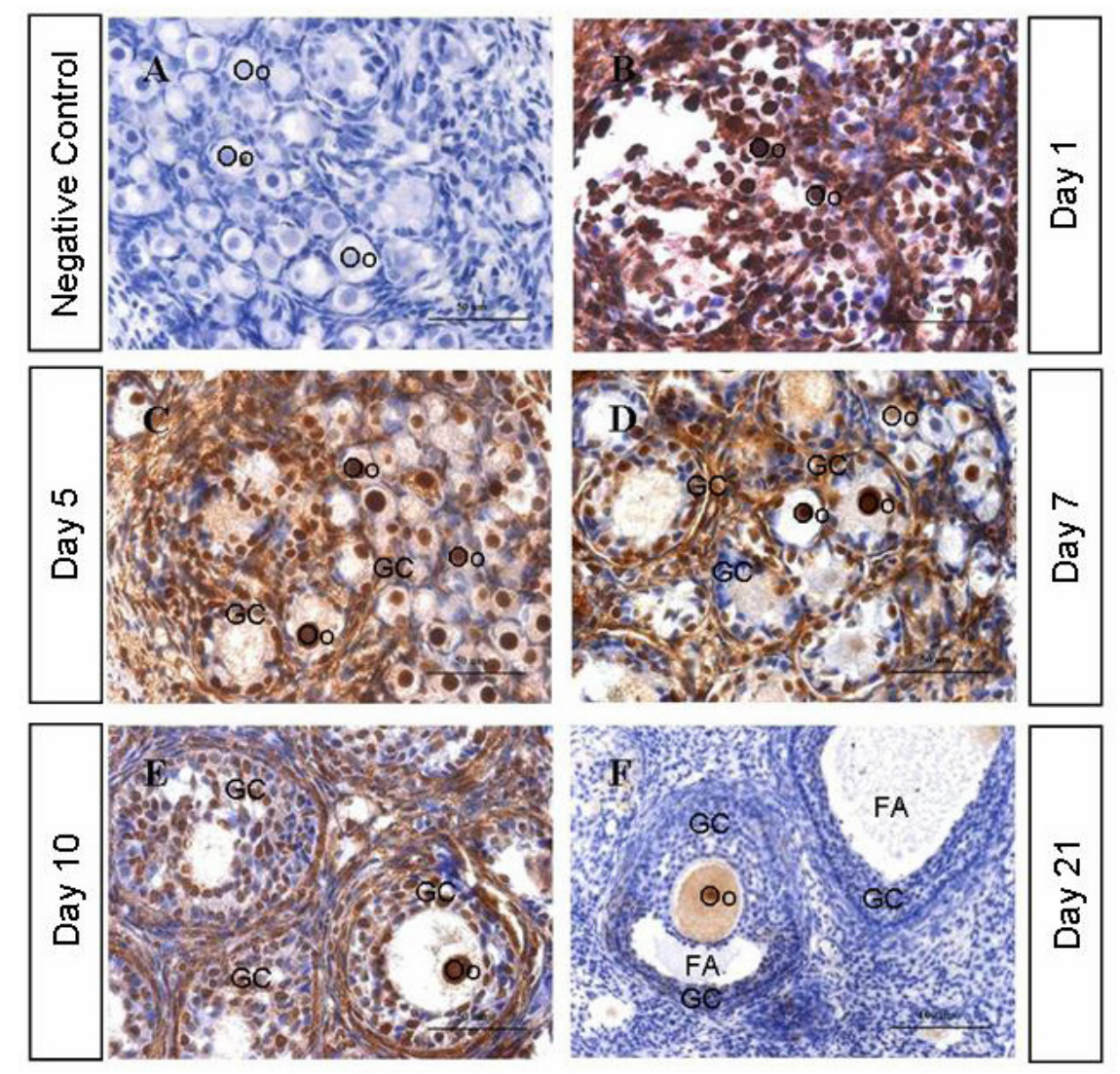

Figure 2. Cellular localization of PCNA protein during follicular growth and development in the ovary on different postnatal days. Ovarian sections were immunostained for PCNA and counterstained with hematoxylin. The PCNA immunohistochemical signals were brown and the counterstaining background was blue in color. Negative controls remained unstained in samples lacking primary antibody instead of serum. $\mathrm{N}=6$ animals in each group. GC: granulosa cell, Oo: oocyte, FA: follicle antrum. 


\section{PCNA and HIF-1 $\alpha$ levels in the ovaries of postnatal rats}

To confirm the above findings, PCNA and HIF-1 $\alpha$ mRNA levels were detected using real-time PCR. During follicular development in postnatal rats, PCNA and HIF-1 $\alpha$ expression increased until day 10 , followed by a decrease in PCNA and HIF-1 $\alpha$ mRNA levels, which may have been caused by the slowing development of ovarian follicles (Figure 3). The results also showed that changes in PCNA mRNA levels were consistent with changes in HIF- $1 \alpha$ mRNA levels $\left(\mathrm{R}^{2}=0.9207\right.$, Figure 3$)$, suggesting that HIF-1 $\alpha$ may participate in follicular development by regulating granulosa cell proliferation in the ovaries of postnatal rats.

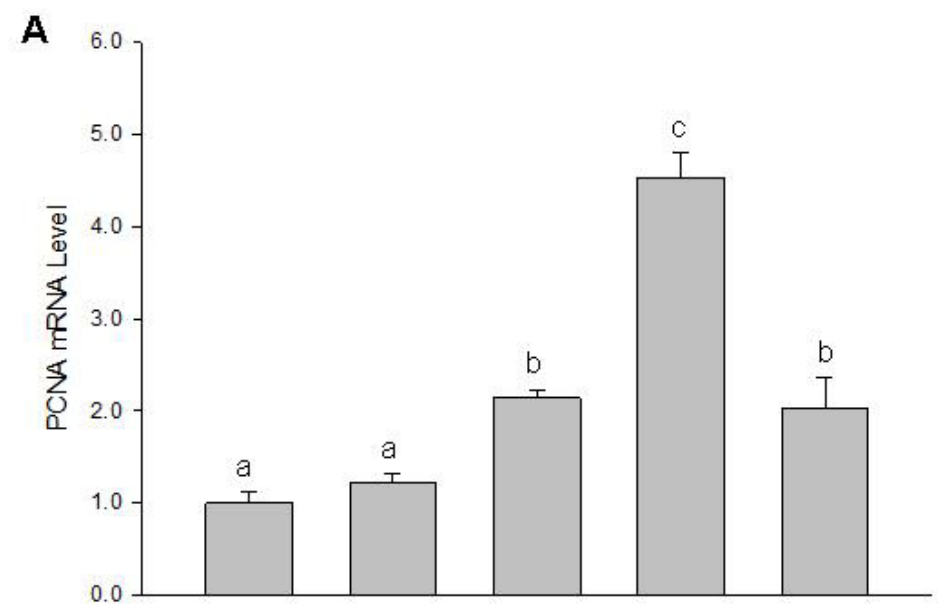

B

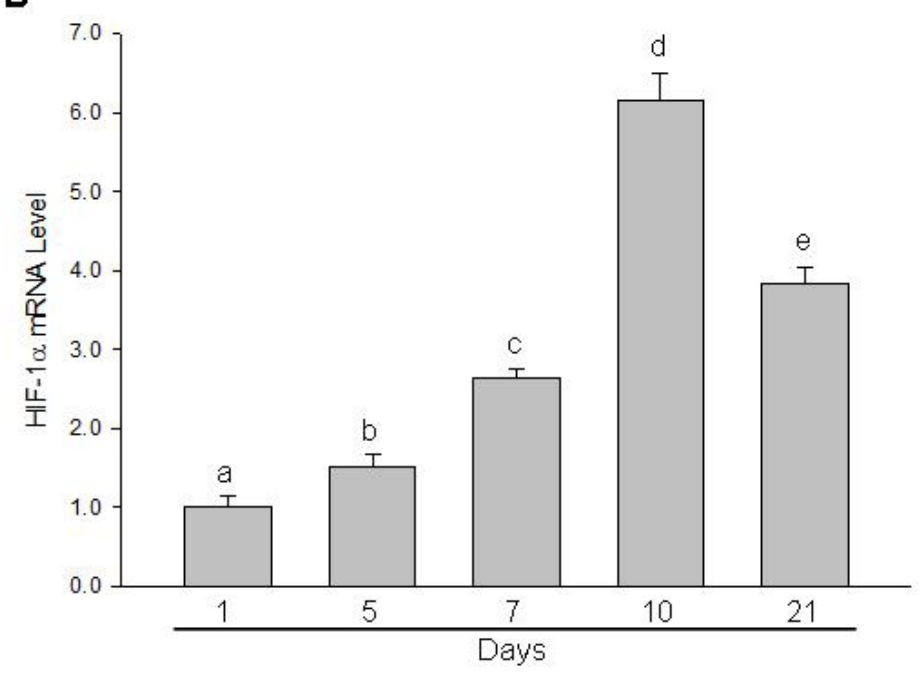

Figure 3. PCNA and HIF-1 $\alpha$ mRNA levels during follicular growth and development in the ovary on different postnatal days. A. Relative mRNA levels of PCNA by real-time reverse transcription-PCR analysis. B. Relative mRNA levels of HIF- $1 \alpha$ by real-time reverse transcription-PCR analysis. Values are reported as means \pm SEM. One-way analysis of variance was used to analyze the data. Different superscripts denote significant differences (P $<0.05$ ) by the Tukey multiple range test. $\mathrm{N}=6$ animals in each group. 


\section{HIF-1 $\alpha$ expression in the ovaries of PMSG-treated immature rats}

In order to further clarify the role of HIF-1 $\alpha$ in follicular development, we used a PMSG-induced follicular development model of immature rats to examine the changes in HIF-1 $\alpha$ expression. Interestingly, PMSG also increased HIF-1 $\alpha$ expression in the granulosa cells of immature rat ovaries during PMSG-induced follicular development (Figure 4), which is consistent with the results of previous studies, which showed that gonadotropins induce HIF-1 $\alpha$ expression in ovarian cells (Huang et al., 2008; Alam et al., 2004, 2009; Brannian et al., 2010).

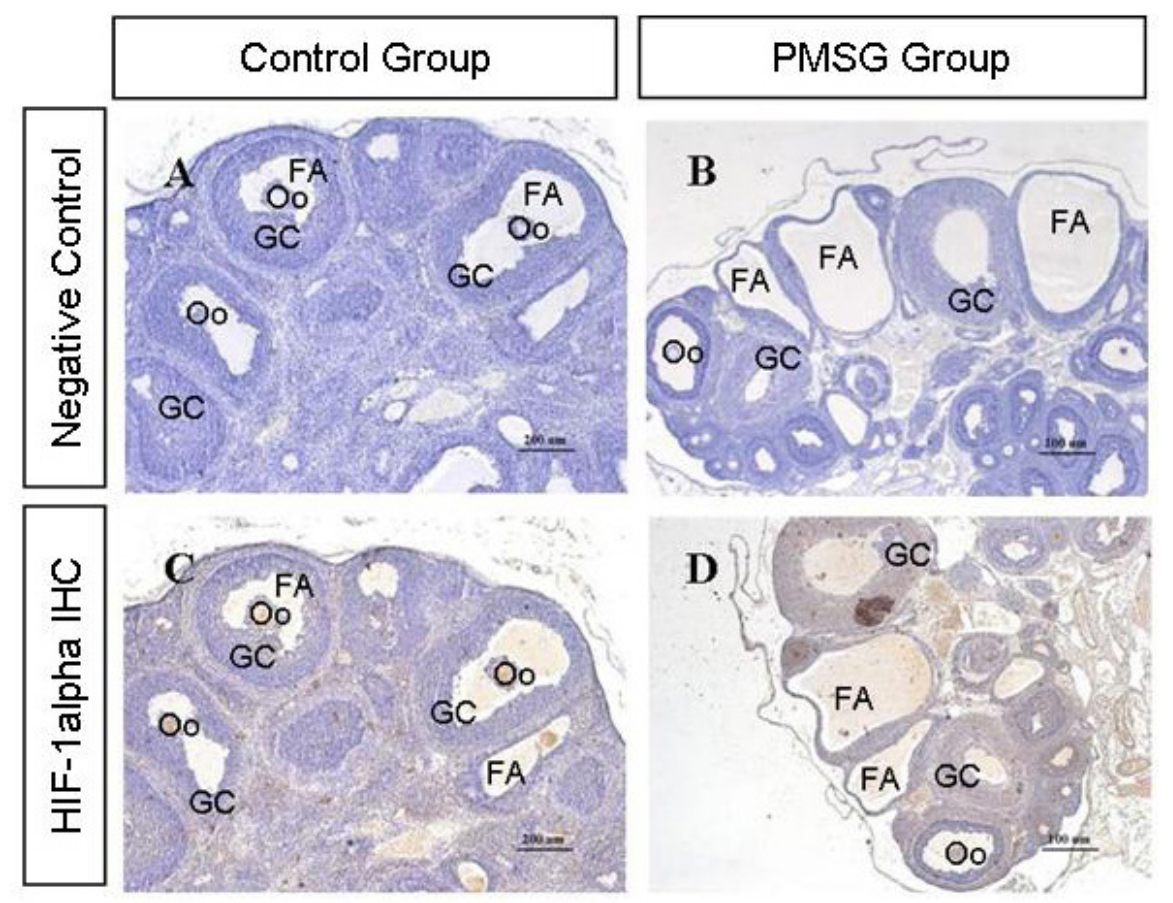

Figure 4. Cellular localization of HIF-1 $\alpha$ protein in the ovary of immature rats primed with PMSG. In order to induce follicular development, the immature rats were treated with 10 IU PMSG and the ovaries were collected for examination of HIF-1 $\alpha$ expression after 48 h PMSG treatment. Ovarian sections were immunostained for PCNA and counterstained with hematoxylin. HIF-1 $\alpha$ immunohistochemical signals were brown and the counterstaining background was blue in color (C and D). PMSG treatment induced follicular development (B) and HIF-1 $\alpha$ expression mainly in granulosa cells (D). Negative controls remained unstained in samples lacking primary antibody instead of serum (A and $\mathbf{B}) . \mathrm{N}=6$ animals in each group. GC: granulosa cell, Oo: oocyte, FA: follicle autrum.

\section{PCNA and HIF-1 $\alpha$ levels in the ovaries of PMSG-treated immature rats}

To verify these results, PCNA expression levels were also examined by western blot. PMSG induced PCNA expression and also induced HIF-1 $\alpha$ expression in the ovaries (Figure 5). These results also showed that the change in PCNA expression levels paralleled the change in HIF-1 $\alpha$ expression (Figure 5), further indicating that HIF-1 $\alpha$ participates in follicular growth and development. 
A

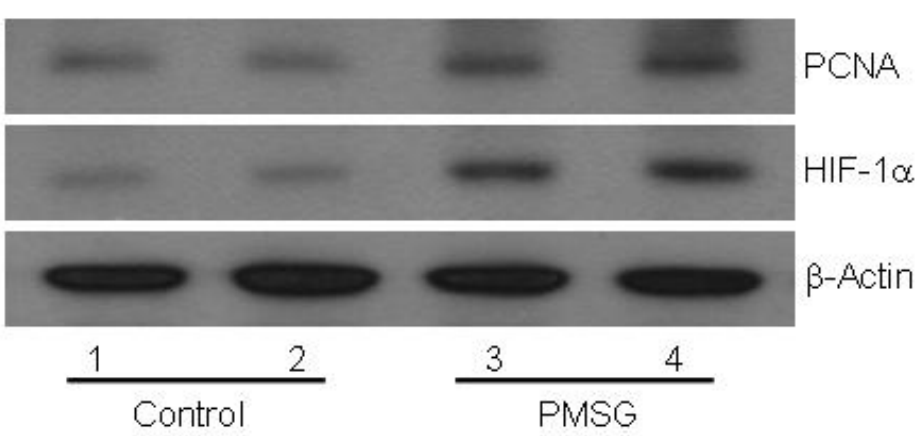

B

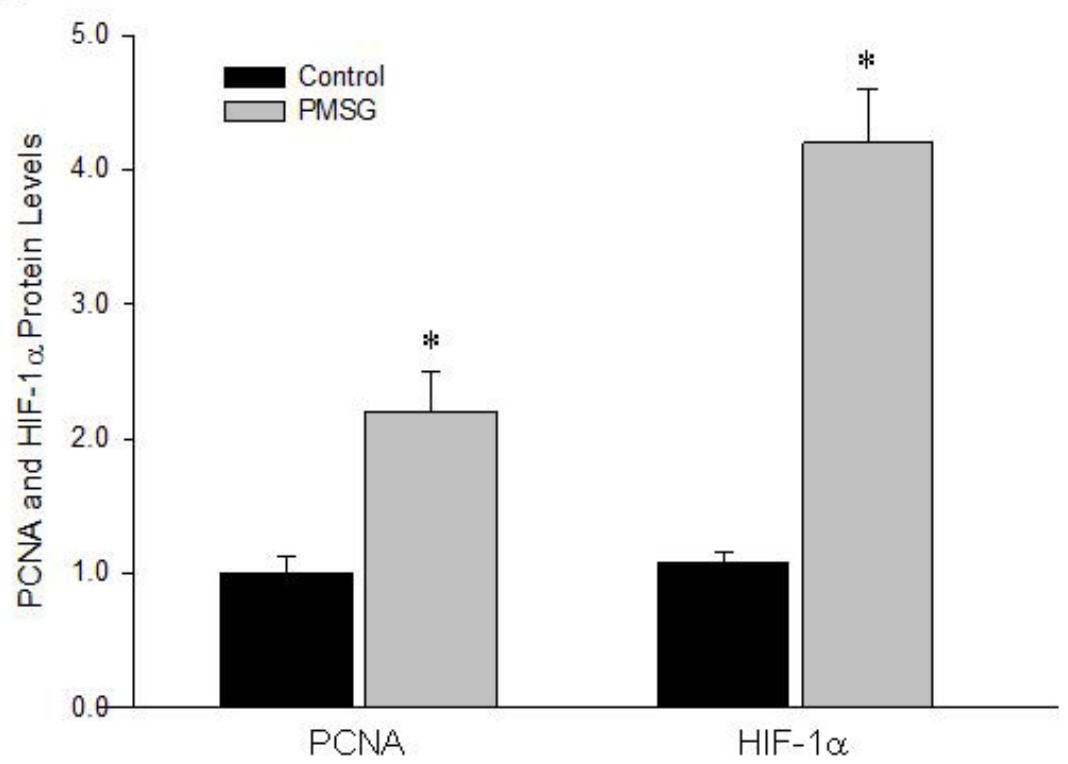

Figure 5. Effects of PMSG on expression levels of PCNA and HIF-1 $\alpha$ proteins in ovaries from immature rats treated with or without PMSG. A. Representative western blot results depicting the protein levels of PCNA and HIF-1 $\alpha$. B. Summarized intensities of PCNA and HIF- $1 \alpha$ blots normalized to the control. An asterisk denotes significant values $(\mathrm{P}<0.05)$ between the 2 groups by the Student $t$-test. $\mathrm{N}=6$ animals in each group.

\section{PCNA and HIF-1 $\alpha$ expression in cultured granulosa cells}

To clarify the possible regulatory mechanism of HIF-1 $\alpha$ during ovarian follicular development, we isolated granulosa cells and cultured the cells with PMSG and HIF-1 $\alpha$ for treatment by siRNA transfection, and then examined the mRNA levels of PCNA and HIF-1 $\alpha$ as they are both expressed in the granulosa cells of ovaries. The results showed PMSG induced HIF- $1 \alpha$ and PCNA expression and that HIF- $1 \alpha$ siRNA blocked this PMSG-induced increase of PCNA mRNA in the granulosa cells (Figure 6). Furthermore, there was a significant correlation between PCNA and HIF-1 $\alpha$ expression $\left(\mathrm{R}^{2}=0.9963\right)$, suggesting that the PCNA-related signaling may be involved in HIF-1 $\alpha$-mediated follicular development in vivo. 

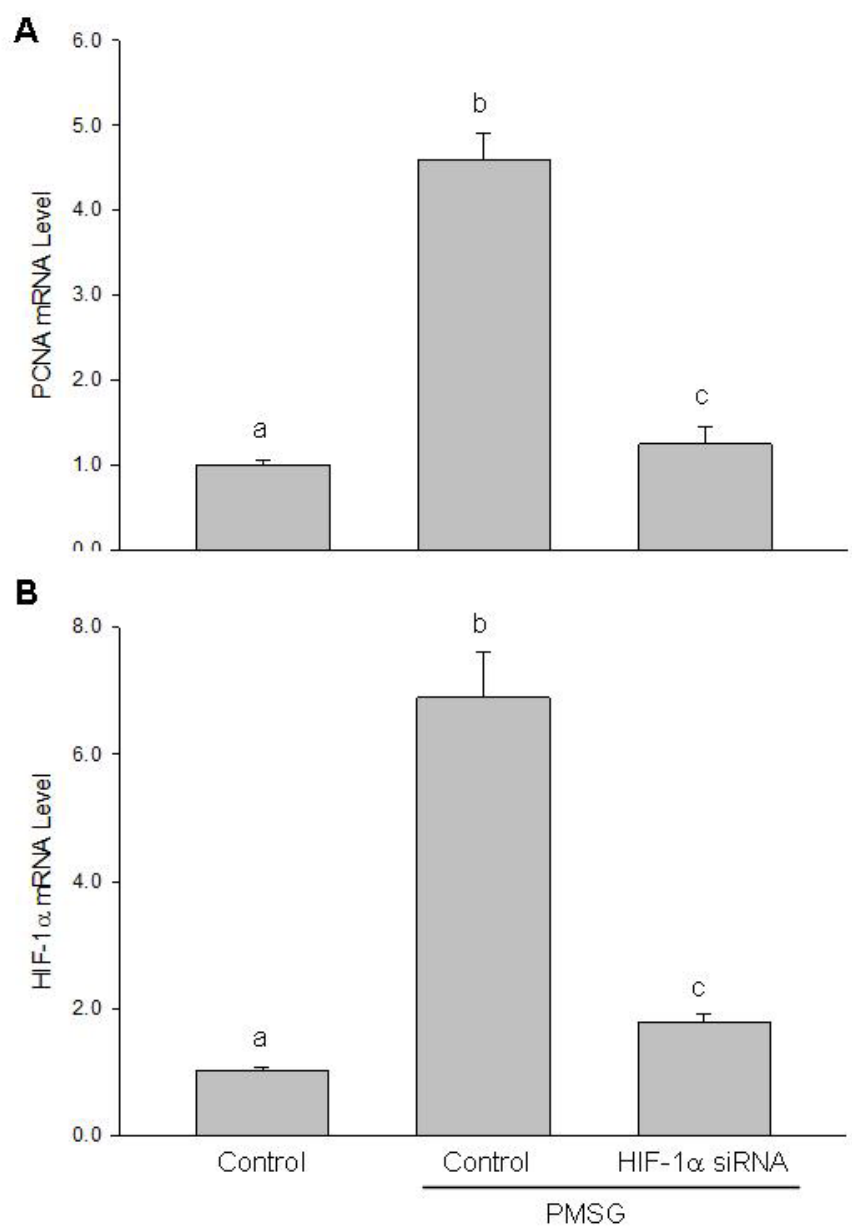

Figure 6. Effects of HIF-1 $\alpha$ siRNA on PCNA mRNA and HIF-1 $\alpha$ mRNA expression in granulosa cells. A. Relative mRNA levels of PCNA by real-time reverse transcription-PCR analysis. B. Relative mRNA levels of HIF-1 $\alpha$ by real-time reverse transcription-PCR analysis. Values are reported as means $\pm \mathrm{SEM}$. One-way analysis of variance was used to analyze the data. Different superscripts denote significant values $(\mathrm{P}<0.05)$ by the Tukey multiple range test. $\mathrm{N}=6$ batches of cells. Control $=$ scramble RNA and/or dimethyl sulfoxide, siRNA $=$ HIF-1 $\alpha$ siRNA.

\section{DISCUSSION}

In this study, we found that ovarian HIF-1 $\alpha$ is expressed mainly in granulosa cells and its expression changes significantly during different developmental stages in postnatal female rats, suggesting that the HIF-1 $\alpha$ signaling plays an important role in follicular growth and development.

The follicular development model of postnatal rats has been widely used in various studies because the follicular development in the rat occurs postnatally (Gelety and Magoffin, 1997; Nilsson et al., 2001; Shi et al., 2004; Wang et al., 2007). The initiation of follicular growth is characterized by the transformation of granulosa cells from a flattened to a cuboidal 
shape and an increase in the number of granulosa cells accompanied by an increase in oocyte size (Wang et al., 2007). The present study revealed that HIF-1 $\alpha$ may participate in the initiation of follicles, as the increase in HIF- $1 \alpha$ coincided with the development of ovarian follicles accompanying the development and proliferation of granulosa cells until day 21. Furthermore, HIF-1 $\alpha$ was also localized in the oocyte with granulosa cells during follicular development at postnatal days $1,5,7,10$, and 21 . From the time of follicular organization and continuing throughout ovulation, the oocyte regulates follicular development by controlling granulosa and thecal cell proliferation and differentiation (Matsumi et al., 1998; van den Hurk and Zhao, 2005; Zhang et al., 2011a). In turn, the granulosa cells are indispensable for oocyte growth and differentiation, nuclear meiotic status, cytoplasmic maturation, and genomic transcriptional activity (Matsumi et al., 1998; van den Hurk and Zhao, 2005; Zhang et al., 2011a). This knowledge, together with the findings of the present study regarding the expression and localizations of HIF-1 $\alpha$ in the rat ovary before puberty, suggests a connection between granulosa cells and oocytes through HIF$1 \alpha$ signaling (Luo et al., 2013a,b). However, the decrease in HIF-1 $\alpha$ expression on day 21 further implies that HIF-1 $\alpha$ plays a vital role in follicular growth and development.

Given the regulation of HIF-1 $\alpha$ by gonadotropins (Huang et al., 2008; Alam et al., 2004, 2009; Brannian et al., 2010), the present study also used another follicular development model of immature rats primed with administration of exogenous gonadotropin PMSG, which offers synchronous recruitment and development of a homogenous cohort of ovarian follicles (Gelety and Magoffin, 1997; Shi et al., 2004; Wang et al., 2007). In addition, many reports have indicated that the expression of HIF- $1 \alpha$ can be induced in ovarian granulosa cells in response to FSH (Alam et al., 2004; Huang et al., 2008; Alam et al., 2009; Brannian et al., 2010). In the present study, an increase of HIF-1 $\alpha$ expression was also observed during follicular development induced by PMSG in this rat model, further implying that HIF-1 $\alpha$ participates in the regulation of follicular development in the ovary.

In addition to examining HIF-1 $\alpha$ expression, we also detected the expression and localization of PCNA during follicular development in the rat ovaries. PCNA is a marker of cell proliferation and plays an important role in cell proliferation. In the ovary, PCNA may also play an important role in follicular growth and development, as the proliferation of granulosa cells has been reported to be involved in this developmental process (Luo et al., 2013a,b). In the present study, PCNA was mainly expressed in the granulosa cells of ovarian developing follicles, which paralleled the expression of HIF-1 $\alpha$. These results further demonstrated that HIF-1 $\alpha$ plays an important role in the mammalian ovaries through granulosa cell proliferation.

Finally, granulosa cell culture was used to further clarify the mechanism of HIF-1 $\alpha$ during follicular development in the ovary. We examined the expression of PCNA and HIF$1 \alpha$ in granulosa cells treated with PMSG and HIF-1 $\alpha$ siRNA. Previous reports showed that administration of exogenous gonadotropin FSH or PMSG could induce HIF-1 $\alpha$ expression in the ovarian granulosa cells (Huang et al., 2008; Alam et al., 2004, 2009; Brannian et al., 2010 ), which is consistent with our present results. Furthermore, HIF-1 $\alpha$ siRNA can block this PMSG-induced expression of HIF-1 $\alpha$ and PCNA. These results further indicated that HIF-1 $\alpha$ participates in controlling follicular growth and development by regulating PCNA-dependent granulosa cell proliferation in vivo (Wang et al., 2011).

In summary, this is the first study to demonstrate that HIF-1 $\alpha$ may regulate follicular growth and development through PCNA-dependent granulosa cell proliferation in vivo. Thus, HIF-1 $\alpha$ signaling may be an important mechanism mediating follicular growth and development in the mammalian ovary, though the detailed mechanism requires further investigation. 
Furthermore, HIF-1 $\alpha$ antagonism may allow for the development of novel treatments for fertility control for some types of ovarian dysfunction such as polycystic ovarian syndrome, ovarian hyperstimulation syndrome, and ovarian neoplasia (Galanis et al., 2008; Miyazawa et al., 2009, 2010; Seeber et al., 2011; Zhang et al., 2012b; Wang et al., 2012).

\section{ACKNOWLEDGMENTS}

Research supported by the National Natural Science Foundation of China (\#31101032 and \#31271255), the Program for New Century Excellent Talents in University of Ministry of Education of China (\#NCET-120614), the Doctoral Foundation of the Ministry of Education in China (\#20113503120002), and the Fujian Provincial Science and Technology Projects of the Department of Education (\#JB14041).

\section{REFERENCES}

Alam H, Maizels ET, Park Y, Ghaey S, et al. (2004). Follicle-stimulating hormone activation of hypoxia-inducible factor-1 by the phosphatidylinositol 3-kinase/AKT/Ras homolog enriched in brain (Rheb)/mammalian target of rapamycin (mTOR) pathway is necessary for induction of select protein markers of follicular differentiation. J. Biol. Chem. 279: 19431-19440.

Alam H, Weck J, Maizels E, Park Y, et al. (2009). Role of the phosphatidylinositol-3-kinase and extracellular regulated kinase pathways in the induction of hypoxia-inducible factor (HIF)-1 activity and the HIF-1 target vascular endothelial growth factor in ovarian granulosa cells in response to follicle-stimulating hormone. Endocrinology 150: 915-928.

Brannian J, Eyster K, Mueller BA, Bietz MG, et al. (2010). Differential gene expression in human granulosa cells from recombinant FSH versus human menopausal gonadotropin ovarian stimulation protocols. Reprod. Biol. Endocrinol. 8: 25.

Galanis A, Pappa A, Giannakakis A, Lanitis E, et al. (2008). Reactive oxygen species and HIF-1 signalling in cancer. Cancer Lett. 266: 12-20.

Gelety TJ and Magoffin DA (1997). Ontogeny of steroidogenic enzyme gene expression in ovarian theca-interstitial cells in the rat: regulation by a paracrine theca-differentiating factor prior to achieving luteinizing hormone responsiveness. Biol. Reprod. 56: 938-945.

Gómez-Raposo C, Mendiola M, Barriuso J, Casado E, et al. (2009). Angiogenesis and ovarian cancer. Clin. Transl. Oncol. 11: $564-571$.

Grimshaw MJ (2007). Endothelins and hypoxia-inducible factor in cancer. Endocr. Relat. Cancer 14: 233-244.

Huang Y, Hua K, Zhou X, Jin H, et al. (2008). Activation of the PI3K/AKT pathway mediates FSH-stimulated VEGF expression in ovarian serous cystadenocarcinoma. Cell Res. 18: 780-791.

Luo Q, Zhang Z, Chen J, Huang X, et al. (2011). Effect of vascular endothelial growth factor on regulation of angiogenesis during early luteal development in live stock. Acta Ecologiae Animalies Domastici. 32: 124-128.

Luo Q, Wu Y, Wu L, Zhang Z, et al. (2013a). Decisive effects of oocytes on the ovulatory process in the mammalian ovary. Chin. J. Cell Biol. 35: 1786-1790.

Luo Q, Wu Y, Zhang Z and Wang Z (2013b). Regulatory effects of granulosa cells on ovarian ovulation in mammalians. Chin. Bull. Life Sci. 25: 621-625.

Matsumi H, Yano T, Koji T, Ogura T, et al. (1998). Expression and localization of inducible nitric oxide synthase in the rat ovary: a possible involvement of nitric oxide in the follicular development. Biochem. Biophys. Res. Commun. 243: 67-72.

Meidan R, Klipper E, Zalman Y and Yalu R (2013). The role of hypoxia-induced genes in ovarian angiogenesis. Reprod. Fertil. Dev. 25: 343-350.

Miyazawa M, Yasuda M, Fujita M, Hirasawa T, et al. (2009). Association of hypoxia-inducible factor-1 expression with histology in epithelial ovarian tumors: a quantitative analysis of HIF-1. Arch. Gynecol. Obstet. 279: 789-796.

Miyazawa M, Yasuda M, Fujita M, Hirabayashi K, et al. (2010). Granulosa cell tumor with activated mTOR-HIF-1alphaVEGF pathway. J. Obstet. Gynaecol. Res. 36: 448-453.

Nilsson E, Parrott JA and Skinner MK (2001). Basic fibroblast growth factor induces primordial follicle development and initiates folliculogenesis. Mol. Cell Endocrinol. 175: 123-130.

Richards JS, Fitzpatrick SL, Clemens JW, Morris JK, et al. (1995). Ovarian cell differentiation: a cascade of multiple 
hormones, cellular signals, and regulated genes. Recent Prog. Horm. Res. 50: 223-254.

Seeber LM, Horree N, Vooijs MA, Heintz AP, et al. (2011). The role of hypoxia inducible factor-1alpha in gynecological cancer. Crit. Rev. Oncol. Hematol. 78: 173-184.

Shi F, Stewart RL Jr, Perez E, Chen JY, et al. (2004). Cell-specific expression and regulation of soluble guanylyl cyclase alpha 1 and beta 1 subunits in the rat ovary. Biol. Reprod. 70: 1552-1561.

van den Hurk R and Zhao J (2005). Formation of mammalian oocytes and their growth, differentiation and maturation within ovarian follicles. Theriogenology 63: 1717-1751.

Wang F, Xiao K, Lin C and Wang Z (2013). Regulatory effects of PI3K signaling on HPG axis in mammalians. Chin. J. Cell Biol. 35: 1068-1072.

Wang Z, Shi F, Jiang YQ, Lu LZ, et al. (2007). Changes of cyclic AMP levels and phosphodiesterase activities in the rat ovary. J. Reprod. Dev. 53: 717-725.

Wang Z, Tang L, Zhu Q, Yi F, et al. (2011). Hypoxia-inducible factor-1 $\alpha$ contributes to the profibrotic action of angiotensin II in renal medullary interstitial cells. Kidney Int. 79: 300-310.

Wang Z, Zhang Z, Wu Y, Chen L, et al. (2012). Effects of echinomycin on endothelin-2 expression and ovulation in immature rats primed with gonadotropins. Exp. Mol. Med. 44: 615-621.

Wu Y, Luo Q, Chen L, Zhang Z, et al. (2012). Regulatory effects of HIF-NOS signaling pathway on NO-dependent functions in mammalian ovary. Chin. J. Biochem. Mol. Biol. 28: 297-303.

Wu Y, Chen L, Zhang Z and Wang Z (2013). Effects of phosphatidylinositol-3 kinase/ protein kinase B/ bone morphogenetic protein-15 pathway on the follicular development in the mammalian ovary. Zhongguo Yi Хие Ke Хие Yиап Хие Bao 35: 224-228

Zhang J, Zhang Z, Wu Y, Chen L, et al. (2012a). Regulatory effect of hypoxia-inducible factor-1 $\alpha$ on hCG-stimulated endothelin-2 expression in granulosa cells from the PMSG-treated rat ovary. J. Reprod. Dev. 58: 678-684.

Zhang W, Wei QW, Wang ZC, Ding W, et al. (2011a). Cell-specific expression and immunolocalization of nitric oxide synthase isoforms and the related nitric oxide/cyclic GMP signaling pathway in the ovaries of neonatal and immature rats. J. Zhejiang Univ. Sci. B 12: 55-64.

Zhang Z, Luo Q, Cheng Y and Wang Z (2012b). Hypoxia-inducible factor-1 alpha signaling: Regulation of vascular endothelial growth factor-dependent angiogenesis during ovarian corpus luteum development in mammals. $J$. Vet. Med. Anim. Health 4: 97-104.

Zhang Z, Yin D and Wang Z (2011b). Contribution of hypoxia-inducible factor-1 $\alpha$ to transcriptional regulation of vascular endothelial growth factor in bovine developing luteal cells. Anim. Sci. J. 82: 244-250.

Zhang Z, Yu D, Yin D and Wang Z (2011c). Activation of PI3K/mTOR signaling pathway contributes to induction of vascular endothelial growth factor by hCG in bovine developing luteal cells. Anim. Reprod. Sci. 125: 42-48. 